\title{
Construction and Standardization of Literary Interest Inventory for the Students of Higher Secondary Schools
}

\author{
Dr. Veenaben Patel $^{1}$, Pro. Dinesh Patel $^{2} *$
}

\section{ABSTRACT}

The literary interest is to be measured and an inventory is prepared for that. In the present inventory students point out whether they like the activity, like it strongly, dislike or strongly dislike. To construct and standardize literary interest inventory for higher secondary school students. To investigate the significant difference in the literary interest of the students between the sub-groups on gender, area, stream, type of school, standard and components of interest inventory. 3119 higher secondary school students is population. Hence survey method was suitable for the present study. The steps of the construction of the inventory are as follows. Items having t- value more than 1.96 and r-value more than 0.20 were selected. Thus, out of the 100 items, 80 items were selected in the final form of the inventory. The reliability of the inventory was established via test-retest method and split-half method. For establishing criterion validity The Teacher Criterion scale that depict various literary activities that can be carried out in higher secondary schools. The null hypotheses were tested using t-test and f-test.

Significant difference is observed in the literary interest of the students with reference to gender. Girls are more inclined towards the literary interest than the boys. Rural students show more interest in literature than the urban students. Students of arts stream show more interest in literature than the students of commerce students and students of science stream show more interest in literature than the students of both streams. Significant difference is students with reference to type of school. Students of grant-in-aid schools show more interest in literature than the students of non-grant-in aid schools.

Keywords: Construction, Standardization, Literary Interest Inventory, High school students

Literature is a way to creative expression of human being. We have experienced best creations of human beings through the medium of literature. Language is the greatest medium of expression for human being. In present education system, ever since the beginning of learning,

\footnotetext{
${ }^{1}$ Professor, Department of Education, Kadi SarvaVishwavidyalaya, Gandhinagar, Gujarat, India

${ }^{2}$ Asst. Professor, S.D. Shethia College of Education, Mundra- kachchh. Gujarat, India

*Responding Author

(c) 2016 I V Patel, D Patel; licensee IJIP. This is an Open Access Research distributed under the terms of the Creative Commons Attribution License (http://creativecommons.org/licenses/by/2.0), which permits unrestricted use, distribution, and reproduction in any Medium, provided the original work is properly cited.
} 


\section{Construction and Standardization of Literary Interest Inventory for the Students Of Higher Secondary Schools}

students are imparted language teaching. It is a matter of thinking whether this language instruction can develop any literary interest among the students or not.

Language is an important stage in the human life. Language is the greatest medium of communication. Language has given human being a distinct identity which is different from other animals. A person can have the best way to express his thoughts with the help of language. Mother tongue of a person is the best language to express thoughts and for the process of thinking.

Gujarati is the mother tongue of the people of Gujarat. Writers from Narsinh Mehta to Niranjan Bhagat have enriched Gujarati language with their creations. We, in schools, help the students enjoy literature through the medium of language. Education will be useful only when the students will utilize whatever he has learnt.

In the present research, an attempt has been made to investigate the literary interest of the higher secondary school students. Gradually, various forms of literature and best literary pieces are taught to students. In this process of education, the present study will be useful to know to what an extent we have been able to develop literary interest among the students.

Standardization of the inventory is the main aspect of the present research. This inventory will be useful to future investigators to know about the interest of the other students. The investigator hopes that the present research will be useful to open a new direction for researches in an interesting subject like literature.

Interest gives birth to creativity. There have been many researches on creativity, but there are very rare researches on literary interest. Many inventories have been prepared to measure occupational interests. But sufficient attempts have not been made for measuring literary interest. The central idea of the present research is to investigate whether the literary forms and literary pieces have developed literary interest among the students or not.

With considerable efforts of school education, how much have we been able to cultivate literary interest among the future generations? The investigator tried to find an answer to this question and decided to standardize literary interest inventory for the higher secondary school students.

\section{Concept of literary interest}

An attempt has been made to know the literary interest of the higher secondary school students. We impart language education to children since the beginning of their learning. Gradually they are taught master pieces of literature through the medium of language. The present study will be useful to know to what extent we have been able to develop literary interest among students.

The investigator has decided to standardize inventory so the inventory will be useful to know the literary interest of the other students of the state. The present study will be useful to develop new researches in an interesting subject like literature. 


\section{Construction and Standardization of Literary Interest Inventory for the Students Of Higher Secondary Schools}

Interest gives birth to creativity. There have been many studies on creativity. But studies on literary interest are rare. Many inventories have been prepared on occupation interest. The central idea behind the study is to know whether the teaching of literary forms and literary pieces develop any literary interest among the students or not.

\section{IMPORTANCE OF THE STUDY}

Literature is closely related with human life. Students come in contact with literature at school level through the medium of language. There have been many attempts in India as well as abroad to measure the interest. Literature is taken as one component in those studies. There have not been sufficient efforts to measure literary interest of the students independently. Hence, this effort to measure the literary interest of the students with reference to Gujarati literature becomes very important.

The past researches did not include components like forms of literature, expression and expression of emotions. In the present study, the investigator has included all these components and tried to measure the literary interest of the students.

\section{OBJECTIVES OF THE STUDY}

No work can be accomplished without objectives. For success of any work objectives must be decided. objective is the soul of the study on the path of which the investigator walks and solves the problem. The objectives of the present study are as under.

1. To construct literary interest inventory for higher secondary school students.

2. To standardize literary interest inventory for higher secondary school students.

3. To investigate the significant difference in the literary interest of the students between the sub-groups on gender, area, stream, type of school and standard.

4. To investigate significant difference in the components of interest inventory among the higher secondary students.

\section{Hypotheses}

Hypotheses are guiding thought or possibilities which are assumed for the solution of problem. It suggests to find out the reasons and for remedy and to note down observations and to interpret information. Hypotheses are steps for study. Investigator moves ahead in research work on the bases of Hypotheses. Hypotheses of the present study are as follows.

1. There will not be significant difference in the mean scores of the Literary Interest Inventory of higher secondary school students with reference to gender.

2. There will not be significant difference in the mean scores of the Literary Interest Inventory of Higher secondary school students with reference to area.

3. There will not be significant difference in the mean scores of the Literary Interest Inventory of higher secondary school students with reference to stream. 


\section{Construction and Standardization of Literary Interest Inventory for the Students Of Higher Secondary Schools}

4. There will not be significant difference in the mean scores of the Literary Interest Inventory of Higher secondary school students with reference to type of school.

5. There will not be significant difference in the mean scores of Literary Interest Inventory of higher secondary school students with reference to standard.

6. There will not be significant difference in the mean scores of the literary components of Literary Interest Inventory of the higher secondary school students.

\section{Delimitations of the Study}

The Delimitations of the study is as follows.

- The present study is restricted to Gujarati medium school run by secondary Education Board of Gujarati state.

- Only selected components of Gujarati Literature are taken to measure Literary interest of the students.

- Interest related to language is not measured in the present study

- In the present study, self - made Literary. Interest Inventory is used. So the limitation of the tool becomes the limitation of the study. The literary interest is measured based on likes and dislikes in the activities. The participation of the students in activities is not taken. The sample is selected via stratified random sampling. The limitation of the technique of the sample selection becomes the limitation of the study.

\section{Operational Definitions of Key Terms}

\section{Literary Interest}

'Literary Interest is not the word of everyday use. The form is made of two words which are defined as follows.

\section{Literature}

According to Sarth Gujarati Jordani kosh 'Literary means related to literature.

According to Bhagvadgvadgomandal (1955) Literature means - imaginative writing in poetry, drama entertaining writing through which pleasure, enthusiasm and preaching emerge. One meaning of 'literature' is more comprehensive. In addition to imaginative writing, when history, economics, philosophy, etc. classical literature merge with it, then it becomes successful writing. Literature binds man with all emotions. Literature is a temple of Godliness of human being. Collection of words is the body of literature. The purity of words, their proper use, harmony of its creation and the clarity of meaning make the beautiful body of literature. Purity of language, purity of words and purity of meaning are essential.

Literature is the art of written works.

Literally translated, the word means “Acquaintance with letters”

- $\quad$ http://en.wikipedia.org/wiki/literary 


\section{Construction and Standardization of Literary Interest Inventory for the Students Of Higher Secondary Schools}

Having to do with the process of creating and writing a document of part thereof -http://org.christiancourses.com/mod/glossary/wiew.php

\section{Interest:}

According to K. G. Desai (Zero) "Interests are activities which a person has shown as a response to questions asked in an inventory. There is a list of activities in Interest Inventories, a person shows that he likes to participate in those activities sometimes, frequently or most often or he says that he does likes very much "

According to sarth Jodanikosh. Interest means liking, affection.

In the present study literary interest means interest of the students related to literature. Interest in writing, reading, listening, narration, comprehension expression of emotions and interest in prose poetry form is to be found out. The students have shown their likes and dislikes in the literary activities of the literary Interest Inventory.

\section{Inventory:}

Inventory means related to research in Inventory it is asked whether a person likes or dislikes activity or how much he likes or dislikes the activity.

"Responses of a person in an inventory cannot be proved right or wrong, but the responses are to be accepted and point towards the activities of inner-self not regarding the activities being right or wrong '”. Desai (2000)

In the present research literary interest is to be measured and an inventory is prepared for that. In the present inventory students point out whether they like the activity, like it strongly, dislike or strongly dislike.

\section{Construction:}

To make, to create, to construct, to make according to norms, In the present study the word 'Construction' is used to refer to the construction of literary interest inventory for students.

\section{Standardization:}

Standardization of literary interest inventory is done based on the validity and reliability of the inventory. Standardization is the process of making an inventory standardized.

\section{Variables of the Study}

To identify and define the variables under the study is an important stage in the research process. For this, it is necessary to understand the variables, their types and their level. The variables under the present study are as under. 
Construction and Standardization of Literary Interest Inventory for the Students Of

Higher Secondary Schools

\begin{tabular}{|c|c|c|c|}
\hline No. & Type if Variable & Variable & Level of Variable \\
\hline 1 & Dependent & $\begin{array}{l}\text { Scores on literary interest } \\
\text { inventory }\end{array}$ & -------- \\
\hline \multirow[t]{5}{*}{2} & Independent & 1. Gender & 1. Boys 2. Girls \\
\hline & & 2. Area & 1. Rural 2. Urban \\
\hline & & 3. Stream & 1. Sci. 2. Com.3.Arts \\
\hline & & 4. Type of School & $\begin{array}{l}\text { 1. Grant-in-aid } \\
\text { 2. Non-grant-in-aid }\end{array}$ \\
\hline & & 5. Standard & 1. XI 2. XII \\
\hline
\end{tabular}

\section{Research Design}

\section{Research Field, Type and Method:}

The present study is considered with the construction and standardization of the literary interest inventory. So, the field of the present study is psychological testing. Considering the aim and applicability, it falls in the category of inventories of the psychological tests.

The main focus of the present study is to investigate the literary interest of the higher secondary school students of Gujarat state. The aim of the study is not to lead towards any principle or rule but to acquire information about some applied data. Hence, the present study is a quantitative and applied type of study.

Higher secondary school students are included in the present study. The sample consists of the groups of higher secondary school students. The results will be applied to all the students of higher secondary schools of Gujarat state. Hence, the present study is of survey type.

\section{Population and Sample}

Students studying in the year 2010-11 in the higher secondary schools run by Gujarat Secondary Education Board become the population of the present study.

Students studying in the higher secondary schools of Gujarat state have been selected as the sample for the present study. The state of Gujarat was divided in five zones. Two districts were selected randomly from each zone. Two talukas were selected randomly from each district. School of Arts, Com. and Science stream were selected randomly from the list of rural and urban area. Again from each school one class of standard XI and one class of standard XII was selected randomly. All the students of the selected class were taken as sample.

Thus, the sample was selected via multi-stage technique. Sample consisted of total 3119 students. Looking at the various variables under the study, girls were 1670 whereas boys were 1449. Students of rural and urban area were 1617 and 1502 respectively. Students of Science, Com. and Arts were 542, 1078 and 1499 respectively. Students of Grant-in-aid and Non-grant- 


\section{Construction and Standardization of Literary Interest Inventory for the Students Of Higher Secondary Schools}

in-aid were 2427 and 692 respectively. Students of standard XI and XII were 1975 and 1144 respectively.

\section{Research Tool}

\section{Construction of Literary Interest Inventory:}

The main aim of the present study was to construct the literary interest inventory. The investigator has taken all care for the construction of the inventory. The steps of the construction of the inventory are as follows.

\section{Pre-piloting:}

A primary form of the inventory was prepared for pre-piloting which had 143 items of 10 different components. This inventory was administered on 66 students.

Proper instructions were given to students. One example was also demonstrated to explain them how to fill in the answer-sheet. After collecting the answer-sheets from the students the responses were scored. The problems of the students were considered and necessary changes were made.

\section{Piloting:}

For pilot study rural and urban schools were selected. Total 400 students of std. XI and XII were selected and the inventory was administered.

The responses of the students were given scores 5,4,3,2 and 1 for their responses a,b,c,d and e respectively. All the responses of the students were scored. The answer-sheets were arranged in the descending order. Then $\mathrm{r}$ and t-value were calculated according to 216 answer-sheets of the upper and lower group consisting $27 \%$ each.

\section{Final Form of the Literary Interest Inventory:}

Items having t- value more than 1.96 and r-value more than 0.20 were selected. Thus, out of the 100 items, 80 items were selected in the final form of the inventory. Thus, the final form of the literary Interest Inventory was prepared.

\section{Reliability of the Literary Interest inventory:}

The reliability of the inventory was established via test-retest method and split-half method. 120 students were selected for test-retest method. After one month, the test was re administered on them. The correlation $r$ was found 0.87 which is positive.

For establishing split-half reliability, the inventory was administered on a group of 150 students. Scores of 40 odd numbered items and 40 even numbered items were obtained. The correlation $\mathrm{r}$ was found 0.96 which is positive. 


\section{Construction and Standardization of Literary Interest Inventory for the Students Of Higher Secondary Schools}

\section{Validity of the Literary Interest Inventory:}

The validity was obtained via face validity, factorial validity and concurrent validity. For face validity, experts of literature and education as well as language teachers of higher secondary schools were consulted and their suggestions were obtained. Necessary changes were made according to their suggestions. 21 such experts were consulted. When necessary, personal meetings were arranged and their guidance was sought. Thus, the changes in components and items were made according to their suggestions and it shows the face validity of the inventory.

For establishing criterion validity correlation was established with the items of literary sections of professional interest inventories of J.H. shah and Surekhaben Amin. 48 items of the literary interest section 12 of the inventory of J.H. Shah were used for establishing validity. The r was found 0.85 which is positives

The Teacher Criterion scale was made having 20 statements that depict various literary activities that can be carried out in higher secondary schools. The language teacher has given responses according to the involvement of the students in the literary activities. The scores of the inventory and the scores given by the teacher were compared and the $r$ was found 0.90 which is positive.

\section{Collection and Analysis of the Data:}

Co-ordination between the research problem and the objectives of the research gives a proper direction to the research process. Framing of objectives is necessary for clear explanation of the research problem. The framing and testing of hypotheses can be possible through the medium of testing the objectives. The research problem can be understood, explained and elaborated through testing the objectives of the study. The objectives of the present study are as follows.

1. To construct a Literary Interest Inventory for the higher secondary school students.

For this aim, literary interest inventory was constructed after deciding 10 components of the interest inventory.

2. To standardize the literary interest inventory for the higher secondary school students.

First, pre-piloting and piloting was carried out. Then reliability was tested through the test-retest method and split-half method. The results were positive. For testing validity, face validity, factorial validity and concurrent validity were tested. The results were positive. Norms were also established.

3. To investigate the difference in the literary interest among the students between the subgroups based on area, sex, type school, standard and stream.

The investigator carried out t-test on the scores of the students with reference to different variables.

4. To investigate the difference between the students in the components of literary interest inventory.

The investigator carried out t-test of the scores of the students with reference to the components of the inventory and fulfilled this objective. 


\section{Construction and Standardization of Literary Interest Inventory for the Students Of Higher Secondary Schools}

Testing of Hypotheses:

\begin{tabular}{|c|c|c|c|c|}
\hline No & Hypothesis & \begin{tabular}{|l}
$t / f$ \\
value
\end{tabular} & $\begin{array}{l}\text { Level of } \\
\text { Significance }\end{array}$ & $\begin{array}{l}\text { Rejected/ } \\
\text { Not rejected }\end{array}$ \\
\hline 1 & $\begin{array}{l}\text { There will not be any significant difference in the } \\
\text { mean scores of the literary interest inventory of the } \\
\text { students with reference to gender. }\end{array}$ & 2.90 & 0.01 & Rejected \\
\hline 2 & $\begin{array}{l}\text { There will not be any significant difference in the } \\
\text { mean scores of the literary interest inventory of the } \\
\text { students with reference to area. }\end{array}$ & 2.81 & 0.01 & Rejected \\
\hline 3 & $\begin{array}{l}\text { There will not be any significant difference in the } \\
\text { mean scores of the literary interest inventory of the } \\
\text { students with reference to stream. }\end{array}$ & 69.75 & 0.01 & Rejected \\
\hline 4 & $\begin{array}{l}\text { There will not be any significant difference in the } \\
\text { mean scores of the literary interest inventory of the } \\
\text { students with reference to type of school. }\end{array}$ & 4,88 & 0.01 & Rejected \\
\hline 5 & $\begin{array}{l}\text { There will not be any significant difference in the } \\
\text { mean scores of the literary interest inventory of the } \\
\text { students with reference to standard }\end{array}$ & 2.90 & 0.01 & Rejected \\
\hline 6 & $\begin{array}{l}\text { There will not be any significant difference in the } \\
\text { mean scores of the component interest in writing } \\
\text { of the literary interest inventory of the students } \\
\text { with reference to gender. }\end{array}$ & 6.57 & 0.01 & Rejected \\
\hline 7 & $\begin{array}{l}\text { There will not be any significant difference in the } \\
\text { mean scores of component interest in writing of } \\
\text { the literary interest inventory of the students with } \\
\text { reference to area. }\end{array}$ & 1.10 & N.S. & Rejected \\
\hline 8 & $\begin{array}{l}\text { There will not be any significant difference in the } \\
\text { mean scores of the component interest in writing } \\
\text { of the literary interest inventory of the students } \\
\text { with reference to stream. }\end{array}$ & 41.20 & 0.01 & Rejected \\
\hline 9 & $\begin{array}{l}\text { There will not be any significant difference in the } \\
\text { mean scores of the component interest in writing } \\
\text { of the literary interest inventory of the students } \\
\text { with reference to type of school. }\end{array}$ & 2.32 & 0.05 & Rejected \\
\hline 10 & $\begin{array}{l}\text { There will not be any significant difference in the } \\
\text { mean scores of the component interest in writing } \\
\text { of the literary interest inventory of the students } \\
\text { with reference to Standard }\end{array}$ & 2.77 & 0.01 & Rejected \\
\hline
\end{tabular}




\section{Construction and Standardization of Literary Interest Inventory for the Students Of Higher Secondary Schools}

\begin{tabular}{|l|l|l|l|l|}
\hline 11 & $\begin{array}{l}\text { There will not be any significant difference in the } \\
\text { mean scores of the reading interest of the literary } \\
\text { interest inventory of the students with reference to } \\
\text { gender. }\end{array}$ & 6.43 & 0.01 & Rejected \\
\hline 12 & $\begin{array}{l}\text { There will not be any significant difference in the } \\
\text { mean scores of the component reading interest of } \\
\text { the literary interest inventory of the students with } \\
\text { reference to area. }\end{array}$ & 2.40 & 0.05 & Rejected \\
\hline 13 & $\begin{array}{l}\text { There will not be any significant difference in the } \\
\text { mean scores of the component reading interest of } \\
\text { the literary interest inventory of the students with } \\
\text { reference to stream }\end{array}$ & 65.28 & 0.01 & Rejected \\
\hline 14 & $\begin{array}{l}\text { There will not be any significant difference in the } \\
\text { mean scores of the component reading interest of } \\
\text { the literary interest inventory of the students with } \\
\text { reference to type of school }\end{array}$ & 3.73 & 0.01 & Rejected \\
\hline 15 & $\begin{array}{l}\text { There will not be any significant difference in the } \\
\text { mean scores of the component reading interest of } \\
\text { the literary interest inventory of the students with } \\
\text { reference to standard }\end{array}$ & 1.70 & N.S. & Not Rejected \\
\hline 16 & $\begin{array}{l}\text { There will not be any significant difference in the } \\
\text { mean scores of the component interest in narrating } \\
\text { of the literary interest inventory of the students } \\
\text { with reference to gender. }\end{array}$ & 5.72 & 0.01 & Rejected \\
\hline 17 & $\begin{array}{l}\text { There will not be any significant difference in the } \\
\text { mean scores of the component interest in narrating } \\
\text { of the literary interest inventory of the students } \\
\text { with reference to area. }\end{array}$ & $\begin{array}{l}\text { 1.05 } \\
\text { of the literary interest inventory of the students } \\
\text { with reference to standard. } \\
\text { mean scores of the component interest in narrating } \\
\text { with reference to stream. }\end{array}$ & N.S. & Not Rejected \\
\hline 19 & $\begin{array}{l}\text { There will not be any significant difference in the } \\
\text { mean scores of the component interest in narrating } \\
\text { of the literary interest inventory of the students } \\
\text { with reference to type school. }\end{array}$ & 3.64 & 0.01 & Rejected \\
\hline 20 & $\begin{array}{l}\text { There will not be any significant difference in the } \\
\text { mean scores of the component interest in narrating }\end{array}$ & 0.70 & N.S. & \\
\hline
\end{tabular}




\section{Construction and Standardization of Literary Interest Inventory for the Students Of Higher Secondary Schools}

\begin{tabular}{|c|c|c|c|c|}
\hline 21 & $\begin{array}{l}\text { There will not be any significant difference in the } \\
\text { mean scores of the component comprehension of } \\
\text { the literary interest inventory of the students with } \\
\text { reference to gender. }\end{array}$ & 5.51 & 0.01 & Rejected \\
\hline 22 & $\begin{array}{l}\text { There will not be any significant difference in the } \\
\text { mean scores of the component comprehension of } \\
\text { the literary interest inventory of the students with } \\
\text { reference to area. }\end{array}$ & 4.36 & 0.01 & Rejected \\
\hline 23 & $\begin{array}{l}\text { There will not be any significant difference in the } \\
\text { mean scores of the component comprehension of } \\
\text { the literary interest inventory of the students with } \\
\text { reference to stream. }\end{array}$ & 28.58 & 0.01 & Rejected \\
\hline 24 & $\begin{array}{l}\text { There will not be any significant difference in the } \\
\text { mean scores of the component comprehension of } \\
\text { the literary interest inventory of the students with } \\
\text { reference to type of school }\end{array}$ & 2.37 & 0.05 & Rejected \\
\hline 25 & $\begin{array}{l}\text { There will not be any significant difference in the } \\
\text { mean scores of the component comprehension of } \\
\text { the literary interest inventory of the students with } \\
\text { reference to standard. }\end{array}$ & 1.05 & N.S. & Not Rejected \\
\hline 26 & $\begin{array}{l}\text { There will not be any significant difference in the } \\
\text { mean scores of the component interest in audio- } \\
\text { visual programmes of literature of the literary } \\
\text { interest inventory of the students with reference to } \\
\text { gender. }\end{array}$ & 8.78 & 0.01 & Rejected \\
\hline 27 & $\begin{array}{l}\text { There will not be any significant difference in the } \\
\text { mean scores of the component interest in audio- } \\
\text { visual programmes of literature of the literary } \\
\text { interest inventory of the students with reference to } \\
\text { area. }\end{array}$ & 1.18 & N.S. & $\begin{array}{l}\text { Not } \\
\text { Rejected }\end{array}$ \\
\hline 28 & $\begin{array}{l}\text { There will not be any significant difference in the } \\
\text { mean scores of the component interest in audio- } \\
\text { visual programmes of literature of the literary } \\
\text { interest inventory of the students with reference to } \\
\text { stream. }\end{array}$ & 39.95 & 0.01 & Rejected \\
\hline 29 & $\begin{array}{l}\text { There will not be any significant difference in the } \\
\text { mean scores of the component interest in audio- } \\
\text { visual programmes of literature of the literary } \\
\text { interest inventory of the students with reference to } \\
\text { type of school. }\end{array}$ & 2.74 & 0.01 & Rejected \\
\hline
\end{tabular}




\section{Construction and Standardization of Literary Interest Inventory for the Students Of Higher Secondary Schools}

\begin{tabular}{|c|c|c|c|c|}
\hline 30 & $\begin{array}{l}\text { There will not be any significant difference in the } \\
\text { mean scores of the component interest in audio- } \\
\text { visual programmes of literature of the literary } \\
\text { interest inventory of the students with reference to } \\
\text { standard. }\end{array}$ & 2.94 & 0.01 & Rejected \\
\hline 31 & $\begin{array}{l}\text { There will not be any significant difference in the } \\
\text { mean scores of the component interest in } \\
\text { expression of emotions of the literary interest } \\
\text { inventory of the students with reference to gender. }\end{array}$ & 4.93 & 0.01 & Rejected \\
\hline 32 & $\begin{array}{l}\text { There will not be any significant difference in the } \\
\text { mean scores of the component interest in } \\
\text { expression of emotions of the literary interest } \\
\text { inventory of the students with reference to area. }\end{array}$ & 4.07 & 0.01 & Rejected \\
\hline 33 & $\begin{array}{l}\text { There will not be any significant difference in the } \\
\text { mean scores of the component interest in } \\
\text { expression of emotions of the literary interest } \\
\text { inventory of the students with reference to stream. }\end{array}$ & 23.88 & 0.01 & Rejected \\
\hline 34 & $\begin{array}{l}\text { There will not be any significant difference in the } \\
\text { mean scores of the component interest in } \\
\text { expression of emotions of the literary interest } \\
\text { inventory of the students with reference to type of } \\
\text { school. }\end{array}$ & 2.28 & 0.05 & Rejected \\
\hline 35 & $\begin{array}{l}\text { There will not be any significant difference in the } \\
\text { mean scores of the component interest in } \\
\text { expression of emotions of the literary interest } \\
\text { inventory of the students with reference to } \\
\text { standard. }\end{array}$ & 0.77 & N.S. & $\begin{array}{l}\text { Not } \\
\text { Rejected }\end{array}$ \\
\hline 36 & $\begin{array}{l}\text { There will not be any significant difference in the } \\
\text { mean scores of the component interest in poetic } \\
\text { forms of literature of the literary interest inventory } \\
\text { of the students with reference to gender. }\end{array}$ & 9.97 & 0.01 & Rejected \\
\hline 37 & $\begin{array}{l}\text { There will not be any significant difference in the } \\
\text { mean scores of the component interest in poetic } \\
\text { forms of the literary interest inventory of the } \\
\text { students with reference to area. }\end{array}$ & 4.14 & 0.01 & Rejected \\
\hline 38 & $\begin{array}{l}\text { There will not be any significant difference in the } \\
\text { mean scores of the component interest in poetic } \\
\text { forms of the literary interest inventory of the } \\
\text { students with reference to stream. }\end{array}$ & 73.19 & 0.01 & Rejected \\
\hline
\end{tabular}




\section{Construction and Standardization of Literary Interest Inventory for the Students Of Higher Secondary Schools}

\begin{tabular}{|c|c|c|c|c|}
\hline 39 & $\begin{array}{l}\text { There will not be any significant difference in the } \\
\text { mean scores of the component interest poetic } \\
\text { forms of the literary interest inventory of the } \\
\text { students with reference to type of school. }\end{array}$ & 2.44 & 0.05 & Rejected \\
\hline 40 & $\begin{array}{l}\text { There will not be any significant difference in the } \\
\text { mean scores of the component interest in poetic } \\
\text { forms of the literary interest inventory of the } \\
\text { students with reference to standard. }\end{array}$ & 3.98 & 0.01 & Rejected \\
\hline 41 & $\begin{array}{l}\text { There will not be any significant difference in the } \\
\text { mean scores of the component interest in prose } \\
\text { forms of literature of the literary interest inventory } \\
\text { of the students with reference to gender. }\end{array}$ & 9.20 & 0.01 & Rejected \\
\hline 42 & $\begin{array}{l}\text { There will not be any significant difference in the } \\
\text { mean scores of the component interest in the prose } \\
\text { forms of literature of the literary interest inventory } \\
\text { of the students with reference to area. }\end{array}$ & 1.83 & N.S. & $\begin{array}{l}\text { Not } \\
\text { Rejected }\end{array}$ \\
\hline 43 & $\begin{array}{l}\text { There will not be any significant difference in the } \\
\text { mean scores of the component interest in prose } \\
\text { forms of literature of the literary interest inventory } \\
\text { of the students with reference to stream. }\end{array}$ & 75.17 & 0.01 & Rejected \\
\hline 44 & $\begin{array}{l}\text { There will not be any significant difference in the } \\
\text { mean scores of the component interest in prose } \\
\text { forms of literature of emotions of the literary } \\
\text { interest inventory of the students with reference to } \\
\text { type of school. }\end{array}$ & 1.97 & 0.05 & Rejected \\
\hline 45 & $\begin{array}{l}\text { There will not be any significant difference in the } \\
\text { mean scores of the component interest in prose } \\
\text { forms of literature of emotions of the literary } \\
\text { interest inventory of the students with reference to } \\
\text { standard. }\end{array}$ & 4.29 & 0.01 & Rejected \\
\hline 46 & $\begin{array}{l}\text { There will not be any significant difference in the } \\
\text { mean scores of the component interest in } \\
\text { collection of literary documents of the literary } \\
\text { interest inventory of the students with reference to } \\
\text { gender. }\end{array}$ & 8.41 & 0.01 & Rejected \\
\hline 47 & $\begin{array}{l}\text { There will not be any significant difference in the } \\
\text { mean scores of the component interest in } \\
\text { collection of literary documents of the literary } \\
\text { interest inventory of the students with reference to } \\
\text { area. }\end{array}$ & 3.13 & 0.01 & Rejected \\
\hline
\end{tabular}




\section{Construction and Standardization of Literary Interest Inventory for the Students Of Higher Secondary Schools}

\begin{tabular}{|c|c|c|c|c|}
\hline 48 & $\begin{array}{l}\text { There will not be any significant difference in the } \\
\text { mean scores of the component interest in } \\
\text { collection of literary documents of the literary } \\
\text { interest inventory of the students with reference to } \\
\text { stream. }\end{array}$ & 37.19 & 0.01 & Rejected \\
\hline 49 & $\begin{array}{l}\text { There will not be any significant difference in the } \\
\text { mean scores of the component interest in } \\
\text { collection of literary documents of the literary } \\
\text { interest inventory of the students with reference to } \\
\text { type of school. }\end{array}$ & 5.57 & 0.01 & Rejected \\
\hline 50 & $\begin{array}{l}\text { There will not be any significant difference in the } \\
\text { mean scores of the component interest in } \\
\text { collection of literary documents of the literary } \\
\text { interest inventory of the students with reference to } \\
\text { standard. }\end{array}$ & 3.63 & 0.01 & Rejected \\
\hline 51 & $\begin{array}{l}\text { There will not be any significant difference in the } \\
\text { mean scores of the component interest in forms of } \\
\text { literature of the literary interest inventory of the } \\
\text { students with reference to gender. }\end{array}$ & 5.96 & 0.01 & Rejected \\
\hline 52 & $\begin{array}{l}\text { There will not be any significant difference in the } \\
\text { mean scores of the component interest in forms of } \\
\text { literature of the literary interest inventory of the } \\
\text { students with reference to area. }\end{array}$ & 4.04 & 0.01 & Rejected \\
\hline 53 & $\begin{array}{l}\text { There will not be any significant difference in the } \\
\text { mean scores of the component interest in forms of } \\
\text { literature of the literary interest inventory of the } \\
\text { students with reference to stream. }\end{array}$ & 53.15 & 0.01 & Rejected \\
\hline 54 & $\begin{array}{l}\text { There will not be any significant difference in the } \\
\text { mean scores of the component interest in forms of } \\
\text { literature of the literary interest inventory of the } \\
\text { students with reference to type of school. }\end{array}$ & 3.90 & 0.01 & Rejected \\
\hline 55 & $\begin{array}{l}\text { There will not be any significant difference in the } \\
\text { mean scores of the component interest in forms of } \\
\text { literature of the literary interest inventory of the } \\
\text { students with reference to standard. }\end{array}$ & 2.36 & 0.05 & Rejected \\
\hline
\end{tabular}




\section{Construction and Standardization of Literary Interest Inventory for the Students Of Higher Secondary Schools}

Norms of the Literary Interest Inventory:

\section{Norms:}

Significant difference was observed in the mean scores of the literary interest inventory of the higher secondary school students of Gujarat state with reference to sex, area, stream,, type of school and standard. So, the raw scores were converted in to the standard scores. Percentile rank, standard scores and stanine scores of the scores between 150 to 400 were found. In the sample selected for the norms, there were 1670 girls, 1449 boys, rural and urban students were 1617 and 1502 respectively, students of science, commerce and arts stream were 542, 1078 and 1499 respectively, students of grant-in-aid and non grant-in -aid were 2427 and 692 respectively, students of std. XI and XII were 1975 and 1144 respectively. Total number of students in the sample was 3119.

\section{MAJOR FINDINGS}

1. Findings on the literary interest inventory of the entire sample of the higher secondary school students.

Significant difference is observed in the literary interest of the students with reference to gender. Girls are more inclined towards the literary interest than the boys.

Significant difference is observed in the literary interest of the students with reference to area. Rural students show more interest in literature than the urban students.

Significant difference is observed in the literary interest of the students with reference to stream. Students of science stream show more interest in literature than the students of commerce students and students of arts stream show more interest in literature than the students of both streams.

Significant difference is observed in the literary interest of the students with reference to type of school. Students of grant-in-aid schools show more interest in literature than the students of nongrant-in aid schools.

Significant difference is observed in the literary interest of the students with reference to standard. Students of standard XI show more interest in literature than the students of standard XII.

2. Findings on the interest in writing of the higher secondary school students.

Significant difference is observed in the interest in writing with reference to various variables. With reference to gender the girl students, with reference to area the rural students, with reference to stream the arts students, with reference to type of school the grant-in-aid students and with reference to standard the student of standard XI show more interest in the writing component.

3. Findings on the interest in reading of the higher secondary school students. 


\section{Construction and Standardization of Literary Interest Inventory for the Students Of Higher Secondary Schools}

Significant difference is observed in the interest in reading with reference to various variables. With reference to gender the girl students, with reference to area the urban students, with reference to stream the arts students, with reference to type of school the grant-in-aid students and with reference to standard the students of standard XII show more interest in the writing component.

4. Findings on the interest in narrating of the higher secondary school students.

Significant difference is observed in the interest in narrating with reference to various variables. With reference to gender the girl students, with reference to area the rural students, with reference to stream the arts students, with reference to type of school the grant-in-aid students. No significant effect of standard is observed on the interest in narrating of the students.

5. Findings on the interest in comprehension of the higher secondary school students.

Significant difference is observed in the interest in comprehension with reference to various variables. With reference to gender the girl students, with reference to area the rural students, with reference to stream the arts students, with reference to type of school the grant-in-aid students and with reference to standard the student of standard XI show more interest in comprehension component.

6. Findings on the interest of the higher secondary schools in audio-visual programmes of literature

Significant difference is observed in the interest in audio-visual programmes of literature with reference to various variables. With reference to gender the girl students, with reference to area the urban students, with reference to stream the arts students, with reference to type of school the grant-in-aid students and with reference to standard the student of standard XI show more interest in audio-visual programmes of literature.

7. Findings on the interest of the higher secondary schools in expression of emotions.

Significant difference is observed in the interest in audio-visual programmes of literature with reference to various variables. With reference to gender the girl students, with reference to area the rural students, with reference to stream the arts students, with reference to type of school the grant-in-aid students show more interest in the expression of emotions.

No significant effect of standard is observed on the interest in expression of emotions.

8. Findings on the interest of the higher secondary schools in the poetic forms of literature. Significant difference is observed in the interest in audio-visual programmes of literature with reference to various variables. With reference to gender the girl students, with reference to area the rural students, with reference to stream the arts students, with reference to type of school the grant-in-aid students and with reference to standard the students of standard XI show more interest in the poetic form of the literature. 


\section{Construction and Standardization of Literary Interest Inventory for the Students Of Higher Secondary Schools}

9. Findings on the interest of the higher secondary schools in the prose forms of literature.

Significant difference is observed in the interest in the prose forms of literature with reference to various variables. With reference to gender the girl students, with reference to area the rural students, with reference to stream the arts students, with reference to type of school the grant-inaid students and with reference to standard the students of standard XI show more interest in the prose forms of the literature.

10. Findings on the interest of the higher secondary schools in the collection of literary Documents

Significant difference is observed in the interest in the collection of literary documents with reference to various variables. With reference to gender the girl students, with reference to area the rural students, with reference to stream the arts students, with reference to type of school the grant-in-aid students and with reference to standard the students of standard XI show more interest in the collection of literary documents.

11. Findings on the interest of the higher secondary schools in the types of literature Significant difference is observed in the interest in the types of literature with reference to various variables. With reference to gender the girl students, with reference to area the rural students, with reference to stream the arts students, with reference to type of school the grant-inaid students and with reference to standard the students of standard XI show more interest in the types of literature.

\section{Application of the literary Interest Inventory:}

Recently the thinkers and educational and literary institutes have been worrying about the existence of the regional languages. This inventory will be useful to Guajarati Sahitya Parishad, Guajarati Sahitya Academy, various regional literary organizations to plan and implement various programmes for the development of literary interest among future generations.

Results will be also useful to parents also to decide about the development of their children.

With the use of this inventory, educationists, thinkers of literature will be able to plan programmes as and when necessary and bring awareness among people and guide them.

\section{EDUCATIONAL IMPLICATIONS}

The main aim of the present study was to construct and standardize the literary interest inventory for the higher secondary school students. The investigator selected ten components of literary interest and mad a first draft of the inventory. The investigator administered it on a small sample and made necessary changes in the inventory and prepared primary form of inventory. After piloting and item analysis, the final form of the inventory was prepared. Before giving it the final form the reliability and validity of the inventory was tested. Reliability was found very high. Validity was found via three methods and the validity scores were found high which indicate the stability and standardization of the inventory. 


\section{Construction and Standardization of Literary Interest Inventory for the Students Of Higher Secondary Schools}

\section{SUGGESTIONS FOR FUTURE RESEARCH}

The present study was a humble effort in the direction of measuring the literary interest of the higher secondary school students. More studies can be carried out in this direction which is as follows.

1. Construction and try out of the programme for the development of literary interest among the students.

2. Study of literary interest of the students with reference to certain variables.

3. Study of literary creativity and personality

4. Case study of literary creative persons

5. Study of achievement of the students and instructional medias

6. Study of the reflective thinking of the students and the instructional medias

7. Study of the literary interest and occupational choice of the students

8. Study of the literary interest of the students and the values

9. Study of the effectiveness of the audio-visual programmes in the teaching of mother tongue

10. Study of the literary interest and their medias

\section{REFERENCES}

Aggrawal, J . C. (1966). Educational Research: an Introduction. Arya Book Depot, New Delhi. Anne Anastari(1983). Psychological Testing. (Sixth Ed.). New York, MacMillan Pub. Co.

Best, J.W.,(1983). Research in Education. (Fourth Edi) U.S.A. New Delhi, Prentice Hall of India Pvt. Ltd.

David, A. C. et. al.(2004). Technical Brief for the newly Revised Strong Interest Inventory Assessment. Presented at Annual convention of the American Psychological Association, Honolulu, HI, July 28 - August 1, 2004.

Garrett, H. E. And Wood Worth. R. S.(1977).Statistics in Psychology and Education. Bomby, Vakils Feffer and Simon Pvt. Ltd.

Mehrerens, W.A and Lehman I.J.(1973). Measurement and Evaluation in Psychology and Education. New York, Holt Rinehart and Winston Inc.

Minnecota quoted from R. L. Thorndike, E. P. Hagen(1977). Measurment Evaluation in Psychology and Education. (4th Edition),Wiley Easter Limited, New Delhi, Appendix IV Section-F.

Munnroe, P.(1990).History of Education. New Delhi,MacMillan.

Rousseau, D. M. (2000). Psychological Contact Inventory Technical Report. Pittsburgh, USA : Heinz School of Public Policy and Graduate School of Industrial Administration, Carnegie Mellon University.

Strong, E. K. (1943). Jr. Vocational Interests of Men and Women. Stanford University Press.

Super, D.E., Crites and john. O.(1962). Appraising Vocational Fitness. New York, Jointly Published by Harper and Row, New York and John Wither Hill, Inc. 


\section{Construction and Standardization of Literary Interest Inventory for the Students Of Higher Secondary Schools}

\section{Websites:}

Interest Inventories Retrieved December 22, 2008, from http://library,thinkquest.org/J002783/Interinv.htm

Jonathan, Ingram. et. al.(October 25, 2004). Literary Taste: How to Form it Retrieved from http://www.gutenberg.net

Literary (2009). In Webster’s New world College Dictionary Retrieved June 8, 2009, from http://www.yourdictionary.com/literary

Literary Concepts - Elements of a story retrieved December 22, 2008, from http://www.lifestreamcenter.net/DrB/Lessons/LiteraryConcepts.htm

Literary Definitions Retrieved December 22, 2008, from http://www.thefreedictionary.com/literary

Okhade, Sunil. S (Ed.)(2009). Personal Thought : Literary Interests. Retrieved June 08, 2009, from http://www.centralchronicle.com/newscategories.asp?catID=14.

Poetry. In Wikipedia, the free encyclopedia Retrieved December 22, 2008, from http://en.wikipedia.org/wiki/Poetry 